\title{
DYNAMICS OF ENVIRONMENTAL FACTORS IN RELATION TO PHYTOPLANKTON SPECIES IN A POND OF OLD DHAKA, BANGLADESH
}

\author{
SAHAJADI JERIN $^{1}$, MD. ATAUL GANI ${ }^{2}$, MD. ALMUJADDADE ALFASANE $^{1}$ \\ AND MONIRUZZAMAN KHONDKER ${ }^{1}$ \\ ${ }^{1}$ Department of Botany, University of Dhaka, Dhaka-1000, Bangladesh \\ ${ }^{2}$ Department of Botany, Jagannath University, Dhaka-1100, Bangladesh
}

\begin{abstract}
The relationship between different environmental factors and abundance of phytoplankton species was studied for one year in a pond of old Dhaka named Sikkatuli pond. The range of annual mean of different variables in the pond was air and water temperatures $20-31.75^{\circ} \mathrm{C}$, secchi depth $21-54 \mathrm{~cm}, \mathrm{pH} 7.39-8.3$, alkalinity $3.9-9.2$ meq/l, conductivity $484.5-2273.34 \mu \mathrm{S} / \mathrm{cm}$, DO $3.35-8.33 \mathrm{mg} / \mathrm{l}$, TDS $224.67-380.5$ $\mathrm{mg} / \mathrm{l}$, SRS 12.03 - $79.93 \mathrm{mg} / \mathrm{l}, \mathrm{NO}_{3}-\mathrm{N} 0.18$ - $0.435 \mathrm{mg} / \mathrm{l}$, SRP 0.33 - $4.28 \mu \mathrm{g} / \mathrm{l}$, chlorophyll a 196.08 - $362.76 \mu \mathrm{g} / \mathrm{l}$ and phaeopigment 30.51 - $212.2 \mu \mathrm{g} / \mathrm{l}$. During the investigation Cryptomonas erosa var. reflexa, Rhodomonas lens, Cyclotella comensis, Merismopedia gluaca, Euglena acus, Lyngbya limnetica, Chlorella vulgaris, Arthrospira platensis, Trachelomonas volvocina, Oscillatoria agardhii, Synechocystis aquatilis, Pelonema aphane and Peridinium sp. were found to be dominant phytoplankton. Pearson correlation showed that only alkalinity correlated with phytoplankton at $5 \%$ significant level. RDA orientation showed that air temperature, water temperature, secchi depth, chl $a$ and pheopigment concentration are the important environmental factors. RDA ordination plot also showed that phytoplankton species of Pelonema aphane and Peridinium sp. were negatively correlated with secchi depth. Negative correlation was also observed between Trachelomonas volvocina and water temperature.
\end{abstract}

Key words: Environmental factors, Phytoplankton, Old Dhaka, Bangladesh

\section{Introduction}

Mutualistic relationship exists in pond ecosystems between biological communities and environmental factors. The dominance of the algal community promotes the removal of nutrients, organic matter and pathogenic organisms (Curtis and Mara 1994 and Nurdogan and Oswald 1995). In pond ecosystem phytoplankton plays an important role and pond ecosystems play a significant role in the urban life, their existence and water quality. Different environmental factors such as high rainfall, optimum temperature, light help the growth of phytoplankton throughout the year.

Two or three decades earlier, Dhaka city was rich in pond ecosystems but because of rapid urbanization many of these are now extinct. The industrial pollution and domestic organic waste pollution have been considered as a great threat (Khan et al. 1978 and Maroof et al. 1986). High court pond, Dhaka university play ground pond, Press club pond and Shahabag pond are few of those extinct ponds. Recently Govt. of the People's 
Republic of Bangladesh has taken a serious action regarding the extinction of ponds and other wetland habitats. Local inhabitants also become conscious day by day regarding a healthy condition of pond situated in dense urban areas. Sikkatuli pond, Bangshal in old Dhaka is one of them. The present work was carried out to study the dynamics of environmental factors of this pond with particular reference to its phytoplankton population.

\section{Materials and Methods}

Sikkatuli pond located at Kazi Alauddin Road in Bangshal of old Dhaka is demarcated by the geographical coordinates of $23^{\circ} 47^{\circ} 7^{\circ}$ and $90^{\circ} 24^{\circ} 23^{\circ}$ E. According to local people its age is about 150 years. It is square shaped and its total area is about 0.15 hectors. Several sewerage lines come across to the pond from nearby houses which aggravates the water quality of the pond. Thus local inhabitants can't use water for domestic or other purposes. But fish culturing was observed in this pond during the study period.

The investigation was carried out from June 2010 to May 2011 for one year at fortnightly interval and 24 samples were collected. Air temperature, water temperature, secchi depth, $\mathrm{pH}$, total dissolved solids (TDS) and conductivity were measured in situ using portable devices. The water samples for chemical analysis were collected from 0.5 meter depth of water. After collection, the water samples were brought to the National Professor A.K.M Nurul Islam laboratory in the Department of Botany, University of Dhaka for further analysis. Alkalinity was determined after Mackereth et al. (1978) and dissolved oxygen (DO) and soluble reactive silicate (SRS) after Wetzel and Likens (1979), soluble reactive phosphorus (SRP) and nitrate nitrogen $\left(\mathrm{NO}_{3}-\mathrm{N}\right)$ after Murphy and Rilley (1962) and Müller and Wiedemann (1955). Chl $a$ and phaeophytin were determined after Marker $e t$ al. (1980). Samples of Phytoplankton were collected by sedimentation technique with Lugol's solution and quantification of plankton was done with the help of a HBCC (Helber bacterial counting chamber, having a fixed volume $1.005 \mu \mathrm{l}$ ) under compound microscope, Nikon (Optiphot, UFX-11A) fitted with a camera (Nikon FX-35 WA, Japan).

Pearson correlation was done (SPSS v20) to find out the relationship between the environmental factors and total phytoplankton density and Redudancy analysis (RDA) was applied (CANOCO v4.5) to show the relationship between individual phytoplankton species and environmental factors. Prior to RDA analysis air temperature, water temperature and $\mathrm{pH}$ were standardized while rest of the environmental variables were log $(\mathrm{x}+1)$ transformed. Abundance of different phytoplankton species, concentrations of Chl $a$ and phaeopigment was also transformed $\log (\mathrm{x}+1)$ during application of correlation matrix. 


\section{Results and Discussion}

During the present study, monthly mean air and water temperatures were found to be 20$31.75^{\circ} \mathrm{C}$. The fluctuation of air and water temperatures followed almost similar trend throughout the investigation period. The highest air temperature was recorded in June and the lowest was recorded in December (Fig. 1). The effects of water temperature on phytoplankton were directly examined in many aquatic ecosystems and it was found that water temperature strongly regulates the phytoplankton variations (Richardson et al. 2000). Secchi depth (Zs) i.e. the water transparency varied from $21-54 \mathrm{~cm}$ in the pond. Other investigations on different ponds of Dhaka showed a wide variation in secchi depth such as 28.67 - $44.5 \mathrm{~cm}$ in Samad Nagar pond (Akter et al. 2015), 17.05-26.58 cm in Wapda pond (Naher et al. 2015) and 50 to $81 \mathrm{~cm}$ in Bangshal pond (Pramanik et al. 2016). Transparency of water ( $\mathrm{Zs}$ ) is affected mainly due to the increase in the seston load. Monthly mean alkalinity ranged from 3.9-9.2 meq/l. The highest $(9.2 \mathrm{meq} / \mathrm{l})$ and lowest $(3.9 \mathrm{meq} / \mathrm{l})$ fortnightly mean alkalinity were recorded in early April and early September, respectively. In some ponds of Dhaka city alkalinity was recorded to range between $0.48 \mathrm{meq} / \mathrm{l}$ and $7.95 \mathrm{meq} / \mathrm{l}$ (Naher et al. 2015, Akter et al. 2015 and Pramanik et al. 2016). The present observation of fortnightly mean $\mathrm{pH}$ value of $7.39-8.30$ is more or less similar with the results of Nahar et al. (2010) in Joysagor and Pramanik et al. (2016). The highest $(2273.34 \mu \mathrm{S} / \mathrm{cm})$ monthly mean conductivity was found in April while the lowest $(484.5 \mu \mathrm{S} / \mathrm{cm})$ was recorded in November. The conductivity reported by Nahar et al. (2010) was reported to be 4 times lower in Joysagar than the present value. This clearly indicates an increased loading of ions in the pond water. This might be a due to crucial breakdown of organic and inorganic matters in the water body and this was followed by high phytoplankton densities in dry months. DO recorded in the pond showed an overall range of $3.35-8.33 \mathrm{mg} / \mathrm{l}$. The concentration of DO was found to decrease from June and continue till April. There was very low fluctuation in the concentration of DO content in the pond, which might be due to temperature, rainfall and absence of macrophytes in the pond.

The overall range of TDS for the pond was 224.67-380.5 mg/l which was comparable to the result of Pramanik et al. (2016) where TDS ranged from $264.66 \mathrm{mg} / \mathrm{l}$ to $358.6 \mathrm{mg} / \mathrm{l}$. A study from some pond ecosystems of southern part of Bangladesh indicated that TDS range from 5.13-2165 mg/l (Paul 2008). SRS concentration in the water varied from 12.03-79.93 mg/l. Similar observation was also made by Nahar et al. in Joysagar (2010). Silica metabolism is associated with diatom population. According to Welch (1952) much of the soluble silicate is utilized by diatoms which results in the presence of lower silicate in water. The studied pond was very poor in diatom population. Bacillariophyceae was represented by $2 \%$ of the total population. Mean concentration of SRS fluctuated in the same order of magnitude as those observed from Dhaka metropolis (Banu 1995 and Sultana 1997). In the present investigation the concentration of $\mathrm{NO}_{3}-\mathrm{N}$ 
was found to range from $0.18-0.435 \mathrm{mg} / \mathrm{l}$. Some measurements of $\mathrm{NO}_{3}-\mathrm{N}$ carried out by using Hach Kit in some ponds ecosystems in various parts of Bangladesh showed a range of 30.0-1050.0 $\mu \mathrm{g} / \mathrm{l}$ (Zaman et al. 1993). SRP concentration in the pond was found to be high $(0.33-4.28 \mathrm{mg} / \mathrm{l})$ which exceeded the mandatory phosphate limit $(22-300 \mu \mathrm{g} / \mathrm{l})$ specified in the surface water regulations in the EU. This finding indicates a tremendous pollutant load of organic origin in the pond water (Fig. 1).
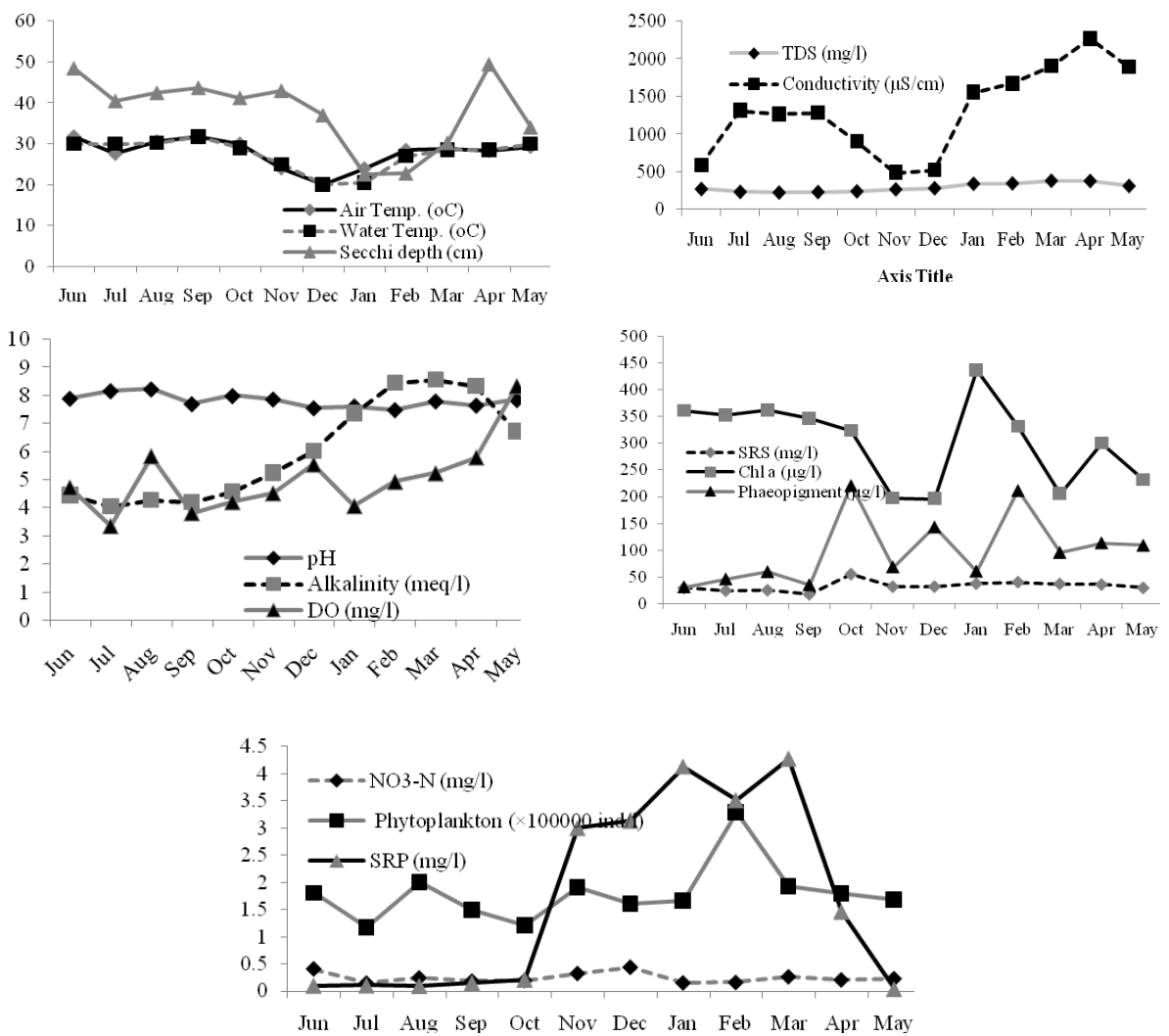

Fig. 1. Monthly variation of different environmental parameters and abundance of phytoplankton observed during the study period.

The biomass of phytoplankton as chl $a$ concentration ranged from 196.08 to $362.76 \mu \mathrm{g} / \mathrm{l}$. The recorded higher chl $a$ concentration than the previous studies in urban ponds (Begum 2008, Akter et al. 2015 and Pramanik et al. 2016) indicates an eutrophic nature of the studied pond. In the present investigation the highest phytoplankton abundance coincided with the highest concentration of $\operatorname{chl} a$. The degraded product of chl a i.e. phaeopigment concentration varied from 30.51-212.2 $\mu \mathrm{g} / \mathrm{l}$ (Fig. 1). 
Table 1. Total number of phytoplankton (genera and species) which was categorized within different classes of algae during the study period.

\begin{tabular}{lll}
\hline \multicolumn{1}{c}{ Class } & No. of genera & No. of species \\
\hline Chlorophyceae & $25(50 \%)$ & $53(40.15 \%)$ \\
Cryptophyceae & $08(16 \%)$ & $12(9.09 \%)$ \\
Bacillariophyceae & $06(12 \%)$ & $13(9.85 \%)$ \\
Euglenophyceae & $06(12 \%)$ & $33(25 \%)$ \\
Cyanophyceae & $04(8 \%)$ & $20(15.15 \%)$ \\
Dinophyceae & $01(2 \%)$ & $01(0.76 \%)$ \\
\hline Total & 50 & 132 \\
\hline
\end{tabular}

Table 2. List of dominant phytoplankton species with their abundance (monthly mean) recorded during study period.

\begin{tabular}{|c|c|c|c|c|c|c|c|c|c|c|c|c|}
\hline \multirow[b]{3}{*}{ Phytoplankton species } & \multicolumn{12}{|c|}{ Month } \\
\hline & Jun & Jul & Aug & Sep & Oct & Nov & Dec & Jan & Feb & Mar & Apr & May \\
\hline & \multicolumn{12}{|c|}{ Density $\left(\times 10^{5} \mathrm{ind} / \mathrm{l}\right)$} \\
\hline Cryptomonas erosa var. reflexa & 3.35 & 2.45 & 2.12 & 1.71 & & & & & & & 1.93 & \\
\hline Rhodomonas lens & 1.54 & 2.16 & & 3.84 & 2.01 & 1.56 & & & & 4.76 & 7.33 & \\
\hline Cyclotella comensis & 2.77 & 2.32 & 2.94 & & 1.84 & 5.44 & 4.22 & 3.42 & 1.66 & 4.35 & 2.94 & \\
\hline Merismopedia glauca & 2.88 & 1.99 & 3.1 & 1.17 & & & 3.36 & 1.36 & 1.87 & 2.05 & 1.93 & \\
\hline Peridinium.sp. & & 3.7 & & & & & & & & 1.95 & & 1.97 \\
\hline Euglena acus & & & 4.03 & & & & & & & & 5.85 & 3.17 \\
\hline Lyngbya limnetica & & & 3.2 & 1.81 & & 2.73 & & 1.36 & & & & \\
\hline Chlorella vulgaris & & & 2.12 & 1.38 & 1.56 & & & & 8.04 & & & \\
\hline Arthrospira platensis & & & & & & 2.03 & & & & & & \\
\hline Trachelomonas volvocina & & & & & & & & 2.24 & & & & \\
\hline Oscillatoria agardhii & & & & & & & & 1.8 & & & & 1.56 \\
\hline Synechocystis aquatilis & & & & & & & & & 12.27 & & & 2.48 \\
\hline Pelonema aphane & & & & & & & & & & 4.1 & & 2.73 \\
\hline
\end{tabular}

In the present study a total of 132 species of phytoplankton belonging to 6 different algal classes was recorded. Highest number of species was recorded from the class Chlorophyceae $(40.15 \%)$ and the lowest number belonged to Dinophyceae $(0.76 \%)$ represented by only one species in the pond (Table 1). During the investigation Cryptomonas erosa var. reflexa, Rhodomonas lens, Cyclotella comensis, Merismopedia glauca, Euglena acus, Lyngbya limnetica, Chlorella vulgaris, Arthrospira platensis, Trachelomonas volvocina, Oscillatoria agardhii, Synechocystis aquatilis, Pelonema aphane and Peridinium sp. were found to be dominant phytoplankton species in different sampling periods. Among them Cyclotella comensis was the most frequent occurring phytoplankton observed through the year except September and May. Synechocystis aquatilis was the highest abundance during February among other dominant 
phytoplankton (Table 2). The abundance of phytoplankton community was found to range from $1.17 \times 10^{6}$ ind $/ 1$ to $3.25 \times 10^{6}$ ind $/ 1$ (Fig. 1). Recent studies on different urban ponds in Dhaka city showed different abundance of phytoplankton such as Samad Nagar Pond: $6.16 \times 10^{6}-26.84 \times 10^{6}$ ind $/ 1$; Bangshal Pond: $5.11 \times 10^{5}-34.9 \times 10^{5}$ and Wapda Pond: $35.20 \times 10^{6}-104.72 \times 10^{6}$ ind/l (Naher et al. 2015, Akter et al. 2015 and Pramanik et al. 2016).

Result of Pearson correlation showed that only alkalinity was positively correlated with phytoplankton abundance at 5\% significant level. Out of 13 environmental factors five were used in RDA analysis according to the Monte Carlo test and the inflation factor (which had to be $\leq 20$ ). The first two ordination axes explained $69.4 \%$ of the variance of the species-environment relation and $21.9 \%$ of the variance of species data (Fig. 2).
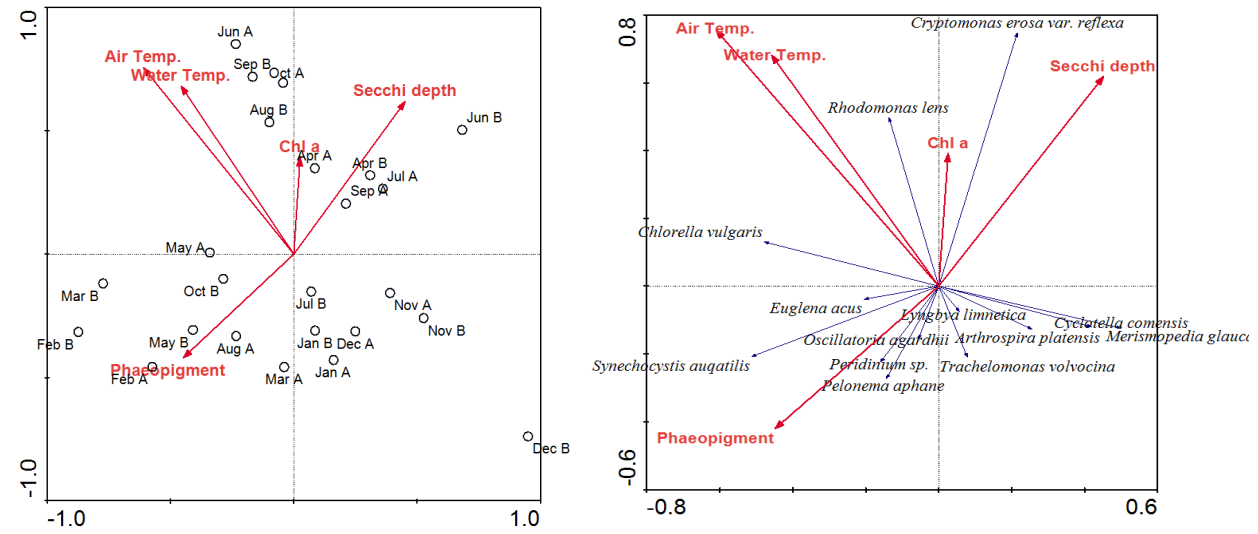

Fig. 2. RDA ordination plot: A. Sampling periods and environmental factors (Air temp., Water Temp., Secchi depth, Chl $a$ and Phaeopigment). B. Phytoplankton species and environmental factors.

Between the two axes in the ordination, axis I1 (eigenvalue $=0.099$ ) showed greater affinities to the environmental variables than axis I (eigenvalue $=0.120$ ). Axis II (eigenvalue $=0.099)$ was positively correlated with air temperature $(r=0.6377)$, water temperature $(\mathrm{r}=0.5753)$, secchi depth $(\mathrm{r}=0.5221)$ and $\mathrm{Chl} a(\mathrm{r}=0.3308)$, while negatively correlated with phaeopigment $(\mathrm{r}=-0.3545)$.

RDA ordination plot also showed that phytoplankton species Pelonema aphane and peridinium sp. were negatively correlated with secchi depth. Negative correlation was also observed between Trachelomonas volvocina and water temperature.

\section{References}

Akter, M., K. Nahar, M.A. Gani and M.M. Alfasane. 2015. Seasonal dynamics of aquatic plants and physicochemical factors in an urban pond of Jatrabari, Dhaka. J.Asiat.Soc. Bangladesh, Sci. 41(2):253-262. 
Banu, H.R. 1995. Hydrobiological study of a and ecosystem in old Dhaka city. M.Sc. Thesis, Dept. Botany, Univ. Dhaka. pp.95.

Begum, Z.N.T. 2008. A Taxonomic account of the phytoplankton of a pond receiving textile industrial effluents. Bangladesh J. Plant Taxon. 15(2): 129-139.

Curtis, T.P. and D.D. Mara. 1994. The effect of sunlight on mechanisms for die-off of faecal Coliform bacteria in waste stabilization ponds. In: Research Monograph No I. University of Leeds, Dept. of Civil Engineering). 94 pp.

Khan, M. R., M. Rahman and A. Huq. 1978. Presence of fecal coliform bacteria in tap water of different localities of Dacca metropolitan city. Bangladesh J. Bot. 7(2):40-45.

Mackereth, F.J.H., J. Heron and J.F. Talling. 1978. Water analysis: some revised methods for limnologists. Freshwater. Biol. Assoc. Publ. 120 pp.

Marker, A.F.H., E.A. Nusch, H. Rai and B. Riemann. 1980. The measurement of photosynthetic pigments in freshwaters and standardization of methods: conclusions and recommendations. Arch. Hydrobiol. Beih. Ergebn. Limnol. 14: 91-106.

Marrof, F. B. A., D. A. Hadi, A. H. Khan and A. H. Chowdhury. 1986. Cadmium and zinc concentrations in drinking water supplies of Dhaka city, Bangladesh. Sci. Tot. Env. 53: 233-238.

Müller, R. and F. Wiedemann. 1955. Die Bestimmung des Nitrats in Wasser. Jahrbuch für Wasserchemie und Wasserreinigungstechnik. Verlag Chemie, Reinbek. 12: 247-271.

Murphy, J. and J.P. Riley. 1962. A modified single solution method for the determination of phosphate in natural waters. Analyt. Chem. Acta. 27:31-36.

Nahar, K. M., Khondker M. and M. Sultana. 2010. Seasonality and Diversity of Epipelic Diatoms in two wetlands of Bangladesh. Bnagladesh J. Bot. 39(1): 29-36.

Naher, M.K, M.A. Gani, K. Nahar and M. Khondker. 2015. Limnological study of Wapda Pond of Jatrabari, Dhaka. Jagannath University Journal of Life and Earth Sciences. 1(1):8-16.

Nurdogan, Y. and W.J. Oswald. 1995. Enhanced nutrient removal in high-rate ponds. Wut. Sci. Technol. 31: 33-34.

Paul, S. 2008. Nannoplankton population dynamics and limnological features of some selected pond ecosystems. M.Sc. Thesis, Dept. of Botany, Univ. Dhaka. pp. 94.

Pramanik, S., M.A. Gani, M.M. Alfasane and M. Khondker. 2016. Seasonality of phytoplankton and their relationship with some environmental factors in an urban pond of old Dhaka. Bnagladesh J. Bot. 45(1):195-201.

Richardson, T.L., C.E. Gibson and S.I. Heaney. 2000. Temperature, growth and seasonal succession of Phytoplankton in Lake Baikal, Siberia. Freshwater Biol. 44: 431-440.

Sultana, M. 1997. A comperative limnology of two ponds of Dhaka Metropolis. M. Sc. Thesis, Dept. of Botany, Univ. Dhaka. pp. 109.

Welch, P. S. 1952. Limnological Methods. Blakiston Co., Philadelphia.538 pp.

Wetzel, R.G. and G.E. Likens. 1979. Limnological analysis. W. B. Saunders Co., Philadelphia. 357 pp.

Zaman, L., M. Khondker and M.R. Nabi. 1993. A comparative limnology of three ponds in Jaahanagirnagar University Campus: physical and chemical aspects. Bangladesh J. Bot. 22(1): 81-87. 